\title{
Gazettes et information politique sous l'Ancien Régime
}

Jean-Paul Bertaud

\section{(2) OpenEdition \\ 12 Journals}

Édition électronique

URL : https://journals.openedition.org/ahrf/1145

DOI : 10.4000/ahrf.1145

ISSN : 1952-403X

Éditeur :

Armand Colin, Société des études robespierristes

\section{Édition imprimée}

Date de publication : 1 septembre 2001

Pagination : 137-138

ISSN : 0003-4436

\section{Référence électronique}

Jean-Paul Bertaud, «Gazettes et information politique sous I'Ancien Régime », Annales historiques de la Révolution française [En ligne], 325 | juillet-septembre 2001, mis en ligne le 10 avril 2006, consulté le 23 avril 2022. URL : http://journals.openedition.org/ahrf/1145 ; DOI : https://doi.org/10.4000/ahrf.1145

Ce document a été généré automatiquement le 23 avril 2022.

Tous droits réservés 


\title{
Gazettes et information politique sous l'Ancien Régime
}

\author{
Jean-Paul Bertaud
}

\section{RÉFÉRENCE}

Gazettes et information politique sous l'Ancien Régime, Actes du colloque de Lyon du 5-7 juin 1997, textes réunis par Henri Duranton et Pierre Rétat, introduction de M.Keith Baker, Publications de l'Université de Saint-Étienne, 444 pages, 1999, $150 \mathrm{~F}$.

Qu'est-ce que la «politique» sous l'Ancien Régime? Qu'est-ce qu'un événement? Qu'est-ce qu'un journal politique? Lors d'un colloque centré sur la nature et le fonctionnement de l'information politique en France et en Europe dans les deux siècles qui précédèrent la Révolution, une quarantaine d'historiens se sont attachés à fournir des réponses à ces questions. L'ouvrage, riche en enseignements sur la presse et la culture politique sous l'Ancien Régime, offre d'abord les contributions qui ont porté sur l'information politique, sur ses supports et ses réseaux, enfin sur ses émetteurs. La censure, la propagande et la représentation du politique sont ensuite traitées tandis qu'un article de J.Censer s'intéresse à la presse et à la Révolution. Enfin une dizaine de contributions interroge le fonctionnement du récit et s'efforce d'approcher le lecteur. L'ouvrage est de première importance pour l'histoire de la presse et de la culture politique sous l'Ancien Régime. 